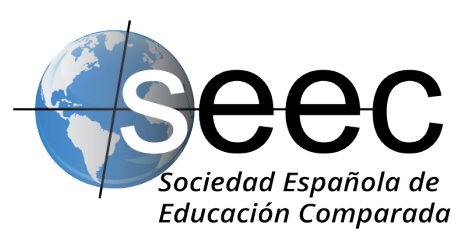

\title{
On Politics in Comparative and International Higher Education
}

Acerca de la política comparada e internacional en Educación Superior

\section{Anatoly Oleksiyenko*}

DOI: $10.5944 /$ reec.40.2022.31203

Recibido: 19 de julio de 2021 Aceptado: 3 de noviembre de 2021

\footnotetext{
*Anatoly Oleksiyenko: Ph.D. (Toronto). Associate Professor, Higher Education. Director, Comparative Education Research Centre (CERC). Editor-in-Chief, Universities \& Intellectuals. Datos de contacto: E-mail: paoleks@hku.hk.
} 


\begin{abstract}
This paper draws attention to key conundrums facing researchers of comparative and international higher education in the age of post-truth and resurgent authoritarianism. The analysis focuses on three salient concerns: world class-universities and academic freedom; power brokerage in the internationalisation of higher education; and challenges of intellectual leadership and integrity, which increasingly challenge research agendas and professionals in the field. Situated at the crossroads of major arguments in the literature and observations derived from academic praxis in these three areas, this critique sets out to explain how politics have been gaining significance in the constructs of comparative and international higher education at a time when corporate elitism is on the rise and the freedoms of inquiry and communication are declining. The study warns about failures of integrity in this context, and manifests imperatives for safeguarding academic freedom and critical research in the field.
\end{abstract}

Keywords: higher education; internationalization; politics; academic freedom; worldclass universities; intellectual leadership.

\title{
Resumen
}

Este artículo analiza las claves que enfrentan los investigadores de la educación superior comparada e internacional en la era de la posverdad y el resurgimiento del autoritarismo. El análisis se centra en tres preocupaciones destacadas: universidades mundiales y libertad académica; correduría de poder en la internacionalización de la educación superior, y retos del liderazgo intelectual, que desafían cada vez más las agendas de investigación y el estudio académico. Situada en la encrucijada de los principales argumentos de la literatura y las observaciones derivadas de la praxis académica en estas tres áreas, esta crítica se propone explicar cómo la política ha ido ganando importancia en los constructos de la educación superior comparada e internacional en un momento en el que el elitismo empresarial está en auge y el aumento y las libertades de investigación y comunicación están disminuyendo. El estudio advierte sobre los riesgos de la integridad en este contexto y manifiesta los imperativos de la salvaguarda de la libertad académica y la investigación crítica en la disciplina comparativa.

Palabras clave: educación superior; internacionalización; política; libertad académica; universidades mundiales; liderazgo intelectual. 


\section{The emerging research agenda}

Politics play a crucial role in shaping the epistemic nature and social structure of higher education. Scholars act as political actors when they define the ideas and methods that are prioritised, sponsored and investigated in universities (Mills 2020; Walker 2020). In major world-class research universities, they also frame the nature of stakeholder support, and determine the order of priorities in teaching, research and service (Cantwell, Coates, and King 2018; Oleksiyenko 2019). However, this is not the case across all universities and epistemic fields. Even in the democratic societies and top universities, the neoliberal economy has been increasingly curtailing freedoms of faculty members and students (Karran and Mallinson 2019; Macfarlane 2016; Tierney 2020). Consequently, the prioritization of corporate or academic interests has a direct effect on the capacities of academic communities to criticise and change outdated social agendas. In the context of social sciences and liberal arts educations, it also affects the reputational positions and ambitions of faculty members in developing theories and methodologies that pave the way for intellectual leadership in global communities of knowledge development (Macfarlane 2013; Oleksiyenko and Ruan 2019). The body of research projects and curricula which create social context cues for external faculty and students about potential career prospects and leadership opportunities in scholarship and idea-making within the created ecosystems, in turn, variously grow and decline in strength (Kim and Locke 2010; Oleksiyenko 2014; Tian and $\mathrm{Lu}$ 2017). In nation-states that increasingly compete for global influence, choices made in favour of either critical thinking or rigid corporate guidance can influence the capacity-building and futurization capabilities of the nation's governance, economy and trade, cross-border relations, and contributions to the world (Li 2018; Lo 2011; Lo and Pan 2021; Oleksiyenko, Zha, Chirikov, and Li 2018).

At the nexus of epistemological and social perspectives, the "glonacalisation" (the process of global+national+local layering) of politics generates yet another layer of problems for shaping the extent to which a university can be successful in achieving its objectives (Rhoades and Marginson 2002; Oleksiyenko et al. 2018). The nature of judgments about local curricula and performance varies across and within stakeholder groups - students, parents, employers, and governments - whose interests are scattered across (and often poorly connected to) the three layers of policy-making in higher education (Clifford and Montgomery 2017). Moreover, in various universities, faculties and departments, the proportions of scholars and stakeholders vary with regard to their allegiance to each layer of scientific, educational, or developmental engagement (Jones and Oleksiyenko 2011). Global, national and local connections can be shaped by universities' histories, cultures, and ambitions, which are reinforced through organisational designs and sagas (Hayhoe, Li, Lin, and Zha 2012; Liu and Metcalfe 2016; Oleksiyenko 2015). Given the global mobility of people and ideas, the political spectrum of inquiries and analyses in university courses and projects is unavoidably vast, even as universities themselves are bounded by the discourses and politics that their states, cities and regions may impose on their institutional networks through policy regulations (King, Marginson and Naidoo 2011).

Notwithstanding the growing complexity of the realities of glonacal higher education, the impact of international politics on this phenomenon remains understudied and under-theorised. Politics is a sensitive subject. The fluidity and mutability of findings and conclusions in this area of studies is high. In view of rapidly changing actors and agendas across national and sub-national systems, policies and practices, the political 
shifts and repositioning strategies within higher education are also often barely traceable or comprehensible. Although multiplying effects of crises (as discussed during the pandemic-related forum of Oleksiyenko, Blanco, Hayhoe et al. 2020, or in the analysis of the Black Lives Matter movement by Bell, Berry, Leopold and Nkomo 2021) make collaborative scholarship and academic activism ever more important, the traditional framework of resource dependencies and center-periphery tensions serves to hinder their development. Separated by ideologies and cultural constraints, academics across disparate societies are unlikely to overcome the barriers to more inclusive and collaborative higher education, if politics are not discussed openly, honestly and patiently. The cross-cultural conversation is noticeably needed when self-censorship spreads in sensitive analytical domains (Lebow 2016; O'Loughlin 2016) and promotion of ideological imperatives grows in demand (Miao and Huang 2020). One question looms particularly larger: What does it take for an academic community to sustain its integrity in a political context where multiple knowledge producers oppose each other's cultural traditions, normative approaches, and epistemological expectations, rather than seek to build an inclusive and tolerant environment for inquiry, learning and problem-solving?

This paper seeks to address these issues by examining the premises of international politics in the context of the growing rivalry between authoritarian regimes (advocating for the needs and priorities of corporate powers) and market-oriented democracies (aspiring to advance the rights of self-governance, but creating hierarchies and exclusivity) (Koch and Vora 2019; Macfarlane 2021a; Oleksiyenko and Tierney 2018). The focus is on several lingering quandaries that amount to anxiety in comparative and international higher education: i.e., world-class university and academic freedom; power-brokerage in the internationalization of higher education; and challenges of intellectual leadership and integrity. The three problem areas are broad, and rather than providing comprehensive treatment, this paper seeks to spark inquiry in domains that generate the forces of politicising research, teaching, and learning in global higher education. Instead of laying out each theme separately, the approach taken here is to create a cascade of arguments from one theme to another, thus producing a more coherent analytical narrative. The framework outlined below, as well as the concluding recommendations, serve that purpose.

\section{World-class university and academic freedom}

Compared to other institutions of higher learning, the world-class university (WCU) can be viewed as a flagship of global higher education (Salmi 2009). The WCU is a research intensive university that brings together talented and competitive international scholars and students, who pursue a robust international research environment that favours critical inquiry and academic excellence (Altbach and Salmi 2011). The pinnacle of the global league of world-class universities attracts the best minds from around the world, who champion intellectual leadership and define the progress of influential scholarship in their knowledge fields (Hazelkorn, 2009; Oleksiyenko and Ruan 2019). Such universities tend to have an organizational culture that values academic freedom and institutional autonomy highly (Karran and Malinson 2019; Salmi 2009). The freedoms to inquire, liaise and communicate stimulate a spirit of conceptual and methodological innovation which attracts other scholars and then positions the research groups formed at WCUs 
for either central or peripheral roles in the global hierarchies and networks of knowledge development (Altbach and Balan 2007). Through their high-quality knowledge production, the WCUs have been defining the organizational field. Worldwide, ambitious universities seek opportunities to join the league of WCUs while emulating organizational behaviours aimed at achieving academic excellence, and being able to compete for the top scholarly brains (Altbach and Balan 2007; Wildavsky 2012).

While most of these conclusions are based on calculative performance statistics in the league (e.g., numbers of top-notch publications and citations, international faculty and students, income generation), the qualitative aspects of achieving world-class status, such as academic freedom and critical inquiry, are largely side-lined (Karran and Malinson 2019). The preference for the former is largely driven by major commercial rankers (Lo 2011), who remain adamant about excluding academic freedom from key criteria in the performance evaluation of institutions pursuing higher metrics in the global university rankings (Holz 2021). Evidently, academic freedom is hard to describe and measure (Karran and Malinson 2019). There are also other challenges impeding the value of the rankers' reputation surveys: e.g., the halo effects in peer assessment of teaching and the research environments (Allen 2021). Meanwhile, the reluctance to include academic freedom as a criterion stands in stark opposition to findings by leading scholars in the field, who convincingly argue that academic freedom, as much as "favourable governance", is essential for developing and sustaining the kind of research that elicits a WCU's top performance in the global leagues (Karran and Mallinson 2019; Mittelman 2017; Salmi 2009). By excluding an assessment of the status of academic freedom when ranking universities, the global rankers show bias, or one may argue, a lack of integrity - given that their predilection for commercial inclusivity is aimed at targeting bigger profits from political regimes that suppress academic freedom, and propelling the pursuit of status goods or governmentally-assigned geopolitical 'gaming' at their leading universities (Chirikov 2021; Holz 2021; Mäkinen 2021; Miao and Huang 2020).

While the commercial interests of non-academic stakeholders are understandable, it may be surprising to observe a similar stance reflected in the choices of researchers in the field of comparative and international higher education, who are also wary of applying the primacy of academic freedom as essential in defining the idea of university. Deceived by the seemingly noble pursuit of creating a more inclusive global framework (notwithstanding research which elucidates the problems with totalitarian regimes who pervert the idea of university - see, for example, Connelly [2014] or Kuraev [2016]), these researchers tend to use the idea of university as a universal one in their conceptualisation and analyses of the organizational field. For the sake of institutional comparisons, it appears to suffice to draw a common denominator around institutional structures engaging a certain number of administrators, professors, and students, who are performing a certain range of institutionally-assigned responsibilities. Within structuralist-functionalist analyses, it appears as if the essence of academic roles, responsibilities and value choices is least important. With the institutional overriding the individual, the university does not need to be a community of liberal inquirers and knowledge developers, who are mandated to use critical thinking to discover the truth and speak it to the power in pursuit of either global knowledge or local problem-solving. With the structuralist-functionalist analytical approach receiving an exclusive emphasis in comparative structuration and hierarchization (in view of this approach being an easier and less controversial unit of analysis, as well as one that creates more credible data, as positivists would argue), it 
does not really matter for the users of analytical products whether academic freedom is at the heart of university research and education.

Downplayed in the conceptualization of the university is the fact that world-class universities, and their research communities in particular, actively advocate for academic freedom (Mittelman 2017; Oleksiyenko 2019), and the higher-ranked universities tend to do this more, according to Karran and Malinson (2019). As Tierney (2020, p. 19) notes, "in a knowledge-driven global society, academic freedom is ever more important as it works directly as an intellectual core for creativity and innovation". Faculty members are more innovative and eager to share their ideas when they have no "fear or concern of retribution" (Tierney 2020, p.17). The high-quality knowledge that is essential for societal improvements tends to emerge only in freedom-oriented research communities, where the Mertonian principles of "disinterestedness" and "organized scepticism" prevail in science (Sztompka 2007). These principles allow for better differentiation between solid and muddled premises in theorisation, research and conclusions, and criticism allows for innovation to gain momentum when scholarly critics are not subject to bullying and revenge (Oleksiyenko 2018). Building on legacies and capacities of critical inquiry, WCUs with traditions of academic freedom resist anti-intellectualism, mono-ideological agendas, and self-censorship. Not only does the genuine WCU do this for its own sake, but also for the larger organizational field of higher education, where other universities aspire to pursue world-class research and teaching. Ideally, the organizational field ultimately benefits from a greater volume of talent pursuing academic excellence, as well as from a higher degree of integrity in academic excellence. The veritable university is eager to absorb these ideals as its institutional agency is primarily an open and self-governed community of scholars, who are eager to improve and innovate as they seek scholarly prominence, as well as seek to create a sustainable environment where academic excellence thrives.

The disinterested and sceptical orientations of academic research are, however, of significant concern to authoritarian regimes that want to retain full control of their professors, public intellectuals, and population at large (Connelly and Grüttner 2010; Connelly 2014; Oleksiyenko 2021a). Academic freedom and excellence measured by global standards is viewed by authoritarians as a threat, and they find it highly problematic when universities urge their faculty and students to engage in critical inquiry and communication (Southall and Cobbing 2001). Authoritarian regimes are particularly concerned about the fields of social sciences and humanities: the sources of critical thinking that challenge dominant agendas, ideologies, and allegiances (Higgins 2013; Jackson 2019; Oleksiyenko 2019). In both the West or the East, corporate managerialism has been pursuing ideological monopoly, while pushing for a reduction in funds for social sciences and humanities, re-orienting them toward so-called "strategic research" (primarily favouring neoliberal marketisation and industrial linkages) and seeding anxiety about employability challenges (Torres and Schugurensky 2002; Vican, Friedman, and Andreasen 2020). By fostering human vulnerability (Oleksiyenko and Tierney 2018), neoliberal authoritarians have been promoting a corporate design of the university which benefits from enhanced hierarchization and monopolization of control over academic resources, symbols, faculty positions, and research/teaching labour (Slaughter and Rhoades 2004). By empowering the corporate professoriate to engage in an assault on the disadvantaged or marginalized, the authoritarians are better able to steer ideological loyalty and make universities serve the needs of corporate governance (Oleksiyenko 2018). Obsessed with 
prestige maximization within the social constructs of their institutions, as well as in the epistemological domains of controlled disciplines, the corporate professoriate is inclined to cultivate power relations that secure lucrative futures for themselves and their networks, while sustaining their entitlements (Slaughter and Rhoades 2004). This allows for a more advantageous distribution of all kinds of perks - e.g., scholarships, visitorships, fellowships, etc., to be steered to compliant followers. Colluding with corporate powers outside academia, the corporate professors stifle critical thinking and freedom of speech in order to preclude any threats to their entitlements and power (Giroux 2015).

\section{Power brokerage in the internationalization of higher education}

While academic freedom remains under-discussed in the context of global neoliberalism and post-truth politics in higher education (Oleksiyenko and Jackson 2020), misuses of freedom and the growth of surrogate academic freedom have been on the rise (Oleksiyenko 2020). If freedom is perceived as an ambiguous but universal good, why wouldn't corporate freedom to use institutions for geopolitics and promotion of posttruth and toxic knowledge make sense as well? If all kinds of universities are universities, and all kinds of freedoms are freedoms, why would authoritarians and their governmental agencies shy away from using them in a way that suits their purposes and interests?

With intensifying competition between nation-states and their economies, the WCU is perceived as a strategic instrument in the soft power toolboxes of these states (Mulvy, 2020). As nationalistic governments increasingly intervene in discourses of internationalisation of higher education, scholars worldwide find it difficult to stay away from nationalistic agendas in their global outreach (Altbach and De Wit 2018; Shahjahan and Kezar 2013). China and Russia, for example, demonstrated how a strategic use of economic wealth, i.e., the financial gains derived from Western investments in financial, human and technological capital to spur economic development on their territories, could be used to restructure and reposition their universities in regional and global educational geopolitics (Hayhoe et al. 2012; Oleksiyenko et al. 2018; Wu 2019). Chankseliani (2021) demonstrated how the state universities of Russia, supported by an imperially-minded government, engage a Sovietised model of international branch campuses to promote Russian political and economic interests abroad. Russian officials have sugar-coated their strategy in neoliberal language; thus, the branch campuses were viewed by an average international, lacking knowledge of Russian language and history, as any typical provider of international higher education services (as in any other GATTS-promoted model of international trades and services - see Oleksiyenko, Chen and Yip 2013). Making good use of the "Sputnik syndrome" (Chirikov 2018) and other travesties which capture the Western imagination (Oleksiyenko 2021b), the Russian government has successfully advanced its interests regionally and globally. Meanwhile, very few questioned the ethics of the internationalization rationale, as described by Chankseliani (2021):

"Why do Russian branch campuses use Russian as the only medium of instruction? The short answer is a policy of Russification. Russia has been implementing extensive Russification policies in the region for many decades. The Soviet Union, to which the Russian Federation is the successor and legal heir, expanded its political influence by implementing a number 
of Russification policies. These included imposing the Russian language as the lingua franca, facilitating the resettlement of ethnic Russians to the colonized countries, rewriting the history curriculum and textbooks, and educating selected individuals in the colonial capital to develop human resources that would serve the colony in the future (Malinovskiy and Chankseliani 2018). These Russification policies weakened national identity in many post-Soviet nation-states, including Kazakhstan (Kissane 2005). Kissane (2005)... acknowledged that history textbooks written by the Soviet authorities represented "Russian colonial conquests of the Republics" as "voluntary and friendly annexations"; textbooks portrayed "Soviet colonization and industrialization" only in a positive light (48)".

Not only did Russia succeed in expanding its soft power in post-Soviet Eurasia, but it also engaged other countries in advancing its neo-imperial rhetoric and practices in other parts of Eurasia. Cognizant of colonial legacies, many developing countries legitimately question the implications of neo-imperial interests abroad, including the co-opting of corrupt government officials in countries with weak economies and poor governance, and throwing of their populations into longitudinal debt (Lumumba-Kasongo 2011; Sherr 2013). In deploying educational "world-classness" as their soft power, some powerbrokers seem to ignore the fact that collaboration-cum-colonisation may be sending problematic messages to the global community. Instead of challenging the idea of imperialism and liberating the higher education discourse and practice from fallacies of the previous decades and centuries, the corporate ideologists seek to simply rejuvenate neo-imperialist methodologies (Oleksiyenko and Li 2018). As "world-class excellence" and "student mobility" become strategic coinage in neo-colonial internationalization, the power-brokers undermine the narratives of a benign global space of higher education, as well as the fledgling trust toward post-totalitarian institutions and communities in the networks of global science.

As a post-truth rhetoric acquires more weight in the international discourse of higher education (Oleksiyenko and Jackson, 2020), concerns about the ethics of internationalisation figure prominently in global academia. Geopolitics mixed with international research frequently create serious misfortunes for faculty who obtain foreign sponsorships (Keen 2021). The recent mistrial of a Chinese professor at the University of Tennessee, Knoxville, demonstrates how problematic cross-border relations can be when governmental policies change radically, international conflicts escalate, and universities lack proper regulations on foreign sponsorships (Redden 2021). While the Tennessee faculty member was accused of concealing his ties with China amidst the US-China conflict, no discussions emerged in that regard on the problems of a neoliberal university that has been urging faculty members to raise external sponsorship money as a means to boost their chances of tenure and promotion (Pietilä and Pinheiro 2021; Sanberg et al. 2014). For some reason, the case did not result in a heightened urgency to examine internationalization ethics as they are managed by the neoliberal academia. The legitimate concern then arises: when is the right time to question the polysemic or post-truth interpretations of internationalization ethics and challenge the money-minded corporate managers? Moreover, who should be doing that? 


\section{Challenges of intellectual leadership}

Calls for enactment of intellectual leadership have emerged as a countermeasure to the problems caused by corporate failures in global academia. Macfarlane (2013) has outlined a range of duties for university professors to embrace as they pursue enhanced integrity and critical thinking amidst the growing corporate assault. His book emphasizes the importance of boundary transgressions and civic engagement as part of the process of knowledge production, fostering an academia in which intellectual leadership implies taking care of vulnerable scholars, the public good and civil society. Oleksiyenko et al. (Tierney in 2018, Ruan in 2019, and Jackson in 2020) have followed up on these suggestions while exploring how academic communities in various countries could confront the challenges to the freedoms of inquiry and speech, and how intellectuals can enhance their capacities for defiance against conformity, fear, and self-censorship. Belief in the transformative powers of human agency features prominently in these studies, and gives rise to hope of a remedy for the ills of corporate academia.

Yet, investigating corporate failures and communicating inconvenient truths to the public are increasingly perilous tasks for academics. Fulfilling one's duties to instigate critical thinking is difficult when corporate powers are consolidated by an institutional agency pursuing hegemonic agendas, as described in the previous two sections. Entrapped by academic careerism (Lok 2019), many professors may prefer to steer clear of topics that create a risk of undermining their opportunities for tenure and promotion (Sutherland 2017). How can intellectual leadership take root in the production of critical research and advocacy for academic freedom when authoritarian states urge intellectuals to prioritise nationalist and cultural allegiances (Altbach and De Wit 2018; Jackson 2019; Shahjahan and Kezar 2013)? In the context of global competition for prestige and status goods, the legitimisation of academic powers depends on the limited resources that corporations are willing to grant only to those who enhance the discourses of trades and services, promotion of techno-capacities, and competitive positioning of national universities in economic globalisation (Slaughter and Rhoades 2004). Critical thinking is a challenge when increasing numbers of scholars opt for self-censorship over risking their security and careers (Lebow 2016; O'Loughlin 2016), and reinforce their allegiances to agendas of their political and epistemological legitimizers (Zhuk 2014).

Highly dependent on industry and governments, many universities have become institutional agencies that promote the de-intellectualization of their professoriate, while emphasizing the steerage and revenue-generating powers of corporate entrepreneurs (Clark 2001; Giroux 2015). Intellectuals are viewed by the corporate managers as "useful" when they comply with regulated and measured performance assignments (Kalfa and Taksa 2017). Corporate academia downplays the fact that it is the free-thinking academics, not the corporate hierarchy, who are the key architects of intellectual leadership, as defined by globally-significant scholarship (Oleksiyenko and Ruan 2019). For managerialists, critical thinkers are actually troublemakers who intensify, rather than reduce, conflicts between the local and the global in university research and teaching (Majhanovich 2020). Critically-minded scholars increasingly have to rely on global standards of science and communication in order to defend their autonomy and freedom from political interventions (Williams 2016). Meanwhile, profit-minded sponsors demand from the professoriate utilitarian applications that enhance economic gains, and accordingly, institutional managers urge their faculty to generate "subsidiary income from the 
commercialization of technology and intellectual property, from co-development and real estate activities undertaken with the private sector, from grants, gifts, contracts and other forms of partnership with the private sector" (Geiger and Sá 2008, p. 165). In this context, corporatized institutions reward publications that enhance ideological servitude, rather than "organized scepticism" and public intellectualism. Given that free-thinkers tend to break boundaries epistemologically and institutionally, while often criticising their institutions and societies (e.g., pointing to pervasive inequalities, failures in the rule of law and justice, repressions of freedoms), and thus exposing the poor performance of corporate elites, those in power often seek opportunities to denigrate their academic critics and curb their autonomy. To be recognized and rewarded, academics are urged to become more pragmatic and contribute to technocratic, profit-making, or ideological agendas that serve the needs of institutional sponsors (Antonov, Lemon, and Mullojonov 2021; Geiger and Sá 2008).

Making commitments to corporate management, many professors cannot help but feel like they are failing to implement their duties in scholarship and citizenship, as their research and teaching contributes little to making societies more democratic, liberal and equitable (Macfarlane 2011; Oleksiyenko 2018). Moulded by corporate templates, academic activism that is measured by indicators in local problem-solving may end up in efforts that ultimately neither resolve problems, nor satisfy local stakeholders (Rhodes, Wright and Pullen 2018; Taylor and Lahad 2018). Good scholarship does not automatically convert ideas into positive societal outcomes, nor does it lend itself to clear tracking of impacts (Chan, Johns and Moses 2018; Marginson 2021). However, by taking responsibility for social projects that they cannot control, or inflating promises of high returns on their social investments for the sake of quick wins in their performance evaluation, the so-called "useful" academics only legitimize corporate control over scholarship, rather than enhance opportunities for critical thinking and innovative research and teaching, which universities should be prioritizing in their institutional missions (Oleksiyenko 2019).

Writing about these dilemmas or challenging institutional governance failures is an increasingly important expression of intellectual leadership, although problematic in view of corporate abuse and growing human vulnerability (Macfarlane 2013; Oleksiyenko and Tierney 2018; Tierney 2020). Assigning blame for institutional failures to managers' or intellectuals' bad choices is more likely to aggravate resentment, than resolve the problems. Writing about institutional failures without mentioning academic choices and duties is an even greater problem. The role of critical inquiry takes on absolute primacy when a self-censoring professoriate chooses to ignore problems, obfuscate terms and agendas, and chastise colleagues who decide to disturb the status-quo, and when the failures of integrity expand and colonise both scholarship and citizenship in academia.

\section{Rethinking power politics}

Power politics become increasingly malignant in the context of competitive and corporatized academia. A preoccupation with institutional or national superiority, intensified by various rankings and political agendas, has blinded many academic actors, leading them to abandon serious deliberations on the idea of university, and fail to see academic freedom and critical research as essential prerequisites for academic existence and excellence. Focused on their ability to sway sponsors, gain prestigious grants, and attract 
international talent, many universities and their corporate elites give high regard to performativity and institutional brand-building, while paying little attention to the needs of innovative scholarship, intellectual leadership, and problem-solving. When intellectuals join the ranks of corporate warriors in various power struggles, global academia loses its genuine value, i.e., as a space for critical thinking and collaborative solutions to endemic problems (poverty, pandemics, wars, discrimination, inequality, environmental degradation, to name a few) that devastate societies and the planet. The freedom of human agency, which has to be a priority in the interest of advancing innovative ideas and mindsets is, unfortunately, relegated to the periphery, as survivalist anxiety takes centre stage along with institutional rigidities.

In the field of comparative and international higher education, there are several significant issues that require more attention in the near future. Traditionally, the focus of comparativists on cross-system performance in policies and outcomes has prevailed, while research on human agency in international higher learning has been scant. Seeking to satisfy positivist peer-reviewers and their preference for calculative research, researchers in the field currently give few insights into the nature and challenges of the human agency in the creation of institutional governance. In many developing and authoritarian countries, the research does not go into depth, partly because the corporate elites tend to respond negatively to potential disloyalty. With increasing control of the peer-review processes by their counterparts in consumerist democracies, who reward and distribute editorial positions, and thus create networks of dependence and loyalty in global science, critical inquiry that challenges managerialism and corporatism is increasingly obfuscated or marginalized in the policy and organizational studies of international higher education. For many authors, working on critical research means facing delays in peerreview processes. Editors often complain about insufficient scholarly input, or scarcity of peer-reviewers who have the ability to properly assess criticisms of nationalism, neoimperialism, corporate assault, and ethical polysemy, especially if papers challenge any preconceived notions of epistemological groups (Zhuk 2014).

When international scholars get stuck within their silos and echo-chambers, subject to ever greater corporate control, and in some places - growing attacks on freedom of expression and nationalistic skewing of research and peer-review, academic integrity is hard to achieve and human vulnerability grows (Oleksiyenko 2018). The choices made by political actors in the field play a significant role in how policies will evolve and influence actions, thinking, and leadership, ultimately impacting the development of society. Provided the choices are well-informed, well-researched and broadly discussed, universities should be able to retain their position as freedom-advocating, knowledge-making and innovative institutions. As such, they should be able to communicate universally and be connected to global networks where place-bounded actors are not bestowed the power or knowledge to control and steer the directions of intellectual inquiry or have a monopoly on wisdom. Globally-valuable and valued knowledge creation should be regarded as such when it is unrestrained by local and national rigidities, no matter how willing restrictive governments may be to re-orient the global flows of ideas. Critical thinking should be the primary driver in globally-rewarded knowledge creation that benefits not a specific nation or its interests, but the global community at large.

Rethinking intellectual leadership in the internationalisation of higher education is thus an urgent priority. As Oleksiyenko, Blanco, Hayhoe, Jackson, Lee, Metcalfe, Sivasubramaniam and Zha (2021) note in their conceptualisation of scholarship 
prospects in the field, internationalisation has to be more concerned with human vulnerability, and must recognize the significance of international collaborations and research in preventing global crises. Internationalisation should see "the other" as an important agency in the construct of global higher learning. Hayhoe (2021) argues that "listening" is an increasingly important skill amidst the noise created by the political rivalries in higher education. Jackson (2021) and Macfarlane (2021b) advocate for "quiet leadership" - a thoughtful, reflective, and critically-minded scholarship concerned with value creation, rather than performative anxiety. The roles of humanities, liberal arts education, religious studies, and cross-disciplinary research are viewed as playing an increasingly important role (Doidge, Doyle and Hogan 2021; Oleksiyenko et al. 2021). What requires more attention from intellectuals are the factors that empower scholars to more deeply examine the challenges of human agency in the processes of internationalization and global engagement within the context of lingering inequity and unresolved marginalization of ethnic, religious, sexual and racial minorities. A commitment to sensitive research themes will thus define the framework of intellectual leadership - as knowledge creation and moral duties go hand in hand.

\section{References}

Allen, R. (2021) Commensuration of the globalised higher education sector: how university rankings act as a credential for world-class status in China. Compare: A Journal of Comparative and International Education, 51(6), 920-938, DOI: 10.1080/03057925.2019.1686607

Altbach, P. G., \& Balán, J. (Eds.). (2007). World Class Worldwide: Transforming Research Universities in Asia and Latin America. Baltimore: Johns Hopkins University Press.

Altbach, P., \& De Wit, H. (2018). Are we facing a fundamental challenge to higher education internationalization?. International Higher Education, (93), 2-4, DOI: 10.6017/ihe.0.93.10414

Altbach, P. G., \& Reisberg, L. (2018). Global trends and future uncertainties. Change: The Magazine of Higher Learning, 50(3-4), 63-67, DOI: 10.1080/00091383.2018.1509601

Altbach, P. G., \& Salmi, J. (Eds.). (2011). The Road to Academic Excellence: The Making of World-Class Research Universities. Washington, DC: World Bank Publications.

Antonov, O., Lemon, E., \& Mullojonov, P. (2021). Academic freedom in Tajikistan: How the suppression, acquiesce and incorporation of intellectuals strengthens the state and affects knowledge production. Central Asian Survey, 1-19, DOI: 10.1080/02634937.2021.1925631

Arday, J., \& Mirza, H. S. (Eds.). (2018). Dismantling Race In Higher Education: Racism, Whiteness And Decolonising The Academy. Cham: Springer.

Bell, M. P., Berry, D., Leopold, J., \& Nkomo, S. (2021). Making Black Lives Matter in academia: a black feminist call for collective action against anti-blackness in the academy. Gender, Work \& Organization, 28, 39-57, DOI: 10.1111/gwao.12555 
Cantwell, B., Coates, H., \& King, R. (Eds.). (2018). Handbook on the Politics of Higher Education. Cheltenham: Edward Elgar Publishing.

Chan, J., Johns, F. and Moses, L.B. (2018). Academic Metrics and Positioning Strategies. In Ajana, B. (Ed.). Metric Culture (pp. 177-195). Bingley: Emerald Publishing Limited.

Chankseliani, M. (2021). The politics of exporting higher education: Russian university branch campuses in the "Near Abroad". Post-Soviet Affairs, 37(1), 26-44, DOI: 10.1080/1060586X.2020.1789938

Chen, G. et al. (2009). Soft Power: China's Emerging Strategy In International Politics. Lanham: Lexington Books.

Chirikov, I. (2018). The Sputnik syndrome: How Russian universities make sense of global competition in higher education. In Oleksiyenko, A., Zha, Q., Chirikov, I., and Jun, L. (eds.). International Status Anxiety and Higher Education: The Soviet Legacy in China and Russia (pp. 259-280). Hong Kong: CERC-Springer. http:// cerc.edu.hku.hk/ product/international-status-anxiety-and-higher-educationthe-soviet-legacy-in-china-russia/

Chirikov, I. (2021). Does Conflict of Interest Distort Global University Rankings?. UC Berkeley Research and Occasional Papers Series, https://escholarship.org/uc/ item/8hk672nh

Clifford, V., \& Montgomery, C. (2017). Designing an internationationalised curriculum for higher education: embracing the local and the global citizen. Higher Education Research \& Development, 36(6), 1138-1151, DOI:10.1080/07294360.2017.1296413

Connelly, J. (2014). Captive University: The Sovietization of East German, Czech, and Polish Higher Education, 1945-1956. Chapel Hill: UNC Press Books.

Connelly, J., \& Grüttner, M. (Eds.). (2010). Universities Under Dictatorship. University Park: Penn State Press.

Doidge, S., Doyle, J., \& Hogan, T.(2020). The universityin the global age: reconceptualising the humanities and social sciences for the twenty-first century. Educational Philosophy and Theory, 52(11), 1126-1138, DOI: 10.1080/00131857.2020.1752186

Geiger, R. L., \& Sá, C. M. (2008). Tapping The Riches Of Science: Universities And The Promise Of Economic Growth. Cambridge: Harvard University Press.

Giroux, H. A. (2015). University In Chains: Confronting The Military-IndustrialAcademic Complex. London and New York: Routledge.

Hazelkorn, E. (2009). Rankings and the battle for world-class excellence: Institutional strategies and policy choices. Higher Education Management and Policy, 21(1), 1-22.

Hayhoe, R. (2021). Cross-cultural understanding and the listening intellect. Universities \& Intellectuals, 1(1), 12-20. 
Hayhoe, R., Li, J., Lin, J., \& Zha, Q. (2012). Portraits of $21^{\text {st }}$ Century Chinese Universities: In the Move to Mass Higher Education (Vol. 30). Dordrecht: Springer.

Higgins, J. (2013). Academic Freedom In A Democratic South Africa: Essays And Interviews On Higher Education And The Humanities. Johannesburg: Wits University Press.

Holtz, C. (2021, April 17). World university rankings are rewarding totalitarianism. University World News https://www.universityworldnews.com/post. php? story=20210413131504585 (Accessed on July 7, 2021).

Jackson, L. (2019). Questioning Allegiance: Resituating Civic Education. London and New York: Routledge.

Jackson, L. (2021). Humility and vulnerability, or leaning in? Personal reflections on leadership and difference in global universities. Universities \& Intellectuals, 1(1), 24-29.

Jones, G. A., \& Oleksiyenko, A. (2011). The internationalization of Canadian university research: A global higher education matrix analysis of multi-level governance. Higher Education, 61(1), 41-57, DOI: 10.1007/s10734-010-9324-8

Kalfa, S., \& Taksa, L. (2017). Employability, managerialism, and performativity in higher education: a relational perspective. Higher Education, 74(4), 687-699, DOI: 10.1007/s10734-016-0072-2

Kamola, I. (2013). Why global? Diagnosing the globalization literature within a political economy of higher education. International Political Sociology, 7(1), 41-58, DOI: 10.1111/ips.12008

Karran, T., \& Mallinson, L. (2019). Academic freedom and world-class universities: A virtuous circle?. Higher Education Policy, 32(3), 397-417, DOI: 10.1057/s41307018-0087-7

Keen, C. (2021). Academic espionage: How international trade law can protect higher education. Georgia Journal of International \& Comparative Law, 49(1), 213-241, https://digitalcommons.law.uga.edu/gjicl/vol49/iss1/9

Kim, T. (2009). Shifting patterns of transnational academic mobility: A comparative and historical approach. Comparative Education, 45(3), 387-403, DOI: 10.1080/03050060903184957

Kim, T. and Locke, W. (2010). Transnational Academic Mobility and The Academic Profession. London: Centre for Higher Education Research and Information, The Open University.

King, R., Marginson, S., \& Naidoo, R. (Eds.). (2011). Handbook On Globalization And Higher Education. Cheltenham: Edward Elgar Publishing.

Kissane, C. (2005). History education in transit: Where to for Kazakhstan? Comparative Education 41(1), 45-69. DOI:10.1080/03050060500073249. 
Koch, N., \& Vora, N. (2019). Laboratories of liberalism: American higher education in the Arabian Peninsula and the discursive production of authoritarianism. Minerva, 57(4), 549-564, DOI: 10.1007/s11024-019-09382-5

Kuraev, A. (2016). Soviet higher education: an alternative construct to the western university paradigm. Higher Education, 71(2), 181-193, DOI: 10.1007/s10734-0159895-5

Kwiek, M. (2014). Changing higher education and welfare states in postcommunist Central Europe: New contexts leading to new typologies?. Human Affairs, 24(1), 48-67, DOI: 10.2478/s13374-014-0205-1

Lebow, R. N. (2016). Self-censorship in international relations and security studies. Journal of Global Security Studies, 1(4), 356-360, DOI: 10.1093/jogss/ ogw013

Lee, J. T. (2015). Soft power and cultural diplomacy: Emerging education hubs in Asia. Comparative Education, 51(3), 353-374, DOI: 10.1080/03050068.2015.1037551

Li, J. (2018). Conceptualizing Soft Power of Higher Education: Globalization and Universities in China and the World. Cham: Springer.

Liu, H., \& Metcalfe, A. S. (2016). Internationalizing Chinese higher education: a glonacal analysis of local layers and conditions. Higher Education, 71(3), 399-413, DOI: 10.1007/s10734-015-9912-8

Lo, T. Y. J., \& Pan, S. (2021). The internationalisation of China's higher education: soft power with 'Chinese characteristics'. Comparative Education, 57(2), 227-246, DOI: $10.1080 / 03050068.2020 .1812235$

Lo, W. Y. W. (2011). Soft power, university rankings and knowledge production: Distinctions between hegemony and self-determination in higher education. Comparative Education, 47(2), 209-222, DOI: 10.1080/03050068.2011.554092

Lok, J. (2019). Why (and how) institutional theory can be critical: Addressing the challenge to institutional theory's critical turn. Journal of Management Inquiry, 28(3), 335349, DOI: $10.1177 / 1056492617732832$

Lomer, S. (2017). Soft power as a policy rationale for international education in the UK: a critical analysis. Higher Education, 74(4), 581-598, DOI: 10.1007/s10734-016oo6o-6

Lumumba-Kasongo, T. (2011). China-Africa relations: A neo-imperialism or a neocolonialism? A reflection. African and Asian Studies, 10(2-3), 234-266, DOI: 10.1163/156921011X587040

Mäkinen, S. (2021). Global university rankings and Russia's quest for national sovereignty. Comparative Education, 1-18, DOI: 10.1080/03050068.2021.1926125

Macfarlane, B. (2013). Intellectual Leadership in Higher Education: Renewing the Role of the University Professor. London and New York: Routledge. 
Macfarlane, B. (2016). Freedom To Learn: The Threat To Student Academic Freedom And Why It Needs To Be Reclaimed. London and New York: Routledge.

Macfarlane, B. (2021a). The neoliberal academic: Illustrating shifting academic norms in an age of hyper-performativity. Educational Philosophy and Theory, 53(5), 459468, DOI: $10.1080 / 00131857.2019 .1684262$

Macfarlane, B. (2021b). In praise of quiet leadership. Universities \& Intellectuals, 1(1), 36-42.

Majhanovich, S. (2020). Neo-liberalism in a globalized world: The case of Canada. In Zajda, J. (ed.). Globalisation, Ideology and Neo-Liberal Higher Education Reforms (pp. 11-29). Dordrecht: Springer, DOI: 10.1007/978-94-024-1751-7

Malinovskiy, S., and Chankseliani, M. (2018). International student recruitment in Russia: Heavy-handed approach and soft-power comeback. In Oleksiyenko, A., Zha, Q., Chirikov, I., and Jun, L. (eds.). International Status Anxiety and Higher Education: The Soviet Legacy in China and Russia (pp. 281-307). Hong Kong: CERC-Springer. http://cerc.edu.hku.hk/ product/international-status-anxietyand-higher-education-the-soviet-legacy-in-china-russia/

Marginson, S., \& Rhoades, G. (2002). Beyond national states, markets, and systems of higher education: A glonacal agency heuristic. Higher Education, 43(3), 281-309, DOI: 10.1023/A:1014699605875

Marginson, S. (2021). Global science and national comparisons: beyond bibliometrics and scientometrics. Comparative Education, 1-22, DOI: 10.1080/03050068.2021.1981725

Miao, W. and Huan, Y. (2021). Politics matters: The power dynamics behind Chinese

English-language humanities and social science journals. Learned Publishing, 34, 331338, DOI: $10.1002 /$ leap.1364

Mills, D. (2020). The epistemic politics of 'academography': navigating competing representations of Africa's university futures. Globalisation, Societies and Education, 18(5), 541-552, DOI: 10.1080/14767724.2020.1814701

Mittelman, J. H. (2017). Implausible Dream: The World-Class University And Repurposing Higher Education. Princeton, NJ: Princeton University Press.

Nielsen, M. W. (2016). Limits to meritocracy? Gender in academic recruitment and promotion processes. Science and Public Policy, 43(3), 386-399, DOI: 10.1093/ scipol/scvo52

O'Loughlin, J. (2016). The perils of self-censorship in academic research in a Wikileaks world. Journal of Global Security Studies, 1(4), 337-345; DOI: 10.1093/jogss/ ogw011

Oleksiyenko, A. (2014). Socio-economic forces and the rise of the world-class research university in the post-Soviet higher education space: the case of Ukraine. European Journal of Higher Education, 4(3), 249-265, DOI: 10.1080/21568235.2014.916537 
Oleksiyenko, A. (2015). Internationalization legacies and collaboration challenges: Postimperial hybrids and political fallouts in Russian higher education. Frontiers of Education in China, 10(1), 23-45, DOI: 10.3868/s110-004-015-0003-7

Oleksiyenko, A. (2016). Higher education reforms and center-periphery dilemmas: Ukrainian universities between neo-Soviet and neo-liberal contestations. In Zaida, J. and Rust, V. (eds.). Globalisation and Higher Education Reforms (pp. 133-148). Springer, Cham.

Oleksiyenko, A. (2018). Zones of alienation in global higher education: Corporate abuse and leadership failures. Tertiary Education and Management, 24(3), 193-205, DOI: $10.1080 / 13583883.2018 .1439095$

Oleksiyenko, A. (2019). Academic Collaborations in the Global Marketplace. Springer International Publishing.

Oleksiyenko, A. (2021a). Is academic freedom feasible in the post-Soviet space of higher education?. Educational Philosophy and Theory, 53(11), 1116-1126, DOI: 10.1080/00131857.2020.1773799

Oleksiyenko,A. (2021b). World-class universities and the Sovietlegacies of administration: Integrity dilemmas in Russian higher education. Higher Education Quarterly, https://doi.org/10.1111/hequ.12306

Oleksiyenko, A., Blanco, G., Hayhoe, R., Jackson, L., Lee, J., Metcalfe, A., Sivasubramaniam, M. \& Zha, Q. (2021). Comparative and international higher education in a new key? Thoughts on the post-pandemic prospects of scholarship. Compare: A Journal of Comparative and International Education, 51(4), 612628, DOI: $10.1080 / 03057925.2020 .1838121$

Oleksiyenko, A., Cheng, K. M., \& Yip, H. K. (2013). International student mobility in Hong Kong: private good, public good, or trade in services?. Studies in Higher Education, 38(7), 1079-1101, DOI: 10.1080/03075079.2011.630726

Oleksiyenko, A. V., \& Jackson, L. (2021). Freedom of speech, freedom to teach, freedom to learn: The crisis of higher education in the post-truth era. Educational Philosophy and Theory, 53(11), 1057-1062, DOI: 10.1080/00131857.2020.1773800

Oleksiyenko, A., \& Ruan, N. (2019). Intellectual leadership and academic communities: Issues for discussion and research. Higher Education Quarterly, 73(4), 406-418, DOI: 10.1111/hequ.12199

Oleksiyenko, A., \& Tierney, W. G. (2018). Higher education and human vulnerability: Global failures of corporate design. Tertiary Education and Management, 24(3), 187-192, DOI: 10.1080/13583883.2018.1439094

Oleksiyenko, A. V., Zha, Q., Chirikov, I., \& Li, J. (eds.). (2018). International Status Anxiety and Higher Education: The Soviet Legacy in China. Hong Kong: CERC/ Springer.

Peters, M. A., Rider, S., Hyvönen, M., \& Besley, T. (Eds.). (2018). Post-Truth, Fake News: Viral Modernity \& Higher Education. Springer. 
Pietilä, M., \& Pinheiro, R. (2021). Reaching for different ends through tenure trackinstitutional logics in university career systems. Higher Education, 81(6), 11971213, DOI: 10.1007/s10734-020-00606-2

Redden, E. (2021, June 18). Mistrial renews concerns about U.S. China Initiative. Inside Higher Ed, Retrieved from https://www.insidehighered.com/news/2021/o6/18/ trial-ut-knoxville-researcher-accused-hiding-chinese-ties-ends-hung-jury

Rhodes, C., Wright, C., \& Pullen, A. (2018). Changing the world? The politics of activism and impact in the neoliberal university. Organization, 25(1), 139-147, DOI: $10.1177 / 1350508417726546$

Salmi, J. (2009). The Challenge Of Establishing World-Class Universities. World Bank Publications.

Sanberg, P. R., Gharib, M., Harker, P. T., Kaler, E. W., Marchase, R. B., Sands, T. D., ... \& Sarkar, S. (2014). Changing the academic culture: Valuing patents and commercialization toward tenure and career advancement. Proceedings of the National Academy of Sciences, 111(18), 6542-6547, DOI: 10.1073/pnas.1404094111

Shahjahan, R. A., \& Kezar, A. J. (2013). Beyond the "national container" addressing methodological nationalism in higher education research. Educational Researcher, 42(1), 20-29, DOI: 10.3102/0013189X12463050

Sherr, J. (2013). Hard diplomacy and soft coercion: Russia's influence abroad. Brookings Institution Press.

Slaughter, S., Slaughter, S. A., \& Rhoades, G. (2004). Academic Capitalism And The New Economy: Markets, State, And Higher Education. Baltimore: Johns Hopkins University Press.

Southall, R., \& Cobbing, J. (2001). From racial liberalism to corporate authoritarianism: The Shell affair and the assault on academic freedom in South Africa. Social Dynamics, 27(2), 1-42, DOI: 10.1080/02533950108458711

Stack, M. (2020). Academic stars and university rankings in higher education: impacts on policy and practice. Policy Reviews in Higher Education, 4(1), 4-24, DOI: 10.1080/23322969.2019.1667859

Sutherland, K. A. (2017). Constructions of success in academia: An early career perspective. Studies in Higher education, 42(4), 743-759, DOI: 10.1080/03075079.2015.1072150

Sztompka, P. (2007). Trust in science: Robert K. Merton's inspirations. Journal of Classical Sociology, 7(2), 211-220, DOI: 10.1177/1468795X07078038

Taylor, Y., \& Lahad, K. (Eds.). (2018). Feeling Academic In The Neoliberal University: Feminist Flights, Fights And Failures. Springer.

Tian, M., \& Lu, G. (2017). What price the building of world-class universities? Academic pressurefacedbyyounglecturersataresearch-centeredUniversityinChina.Teaching in Higher Education, 22(8), 957-974, DOI: 10.1080/13562517.2017.1319814 
Tierney W.G. (2020). The Idea of Academic Freedom and Its Implications for Teaching and Learning. In: Varghese N.V., Mandal S. (eds) Teaching Learning and New Technologies in Higher Education. Singapore: Springer, DOI: 10.1007/978-98115-4847-5_2

Torres, C. A., \& Schugurensky, D. (2002). The political economy of higher education in the era of neoliberal globalization: Latin America in comparative perspective. Higher Education, 43(4), 429-455, DOI: 10.1023/A:1015292413037

Vican, S., Friedman, A., \& Andreasen, R. (2020). Metrics, money, and managerialism: Faculty experiences of competing logics in higher education. The Journal of Higher Education, 91(1), 139-164, DOI: 10.1080/00221546.2019.1615332

Walker, M. (2020). Failures and possibilities of epistemic justice, with some implications for higher education. Critical Studies in Education, 61(3), 263-278, DOI: 10.1080/17508487.2018.1474774

Weiler, H. (2006). Challenging The Orthodoxies Of Knowledge: Epistemological, Structural, And Political Implications For Higher Education. Knowledge, Power And Dissent: Critical Perspectives On Higher Education And Research. Paris: UNESCO Publishing, 61-87.

Wildavsky, B. (2012). The Great Brain Race. Princeton University Press.

Williams, J. (2016). Academic Freedom In An Age Of Conformity: Confronting The Fear Of Knowledge. Dordrecht: Springer.

Wu, H. (2019). Three dimensions of China's "outward-oriented" higher education internationalization. Higher Education, 77(1), 81-96, DOI: 10.1007/s10734-0180262-1

Zapp, M., \& Ramirez, F. O. (2019). Beyond internationalisation and isomorphism-the construction of a global higher education regime. Comparative Education, 55(4), 473-493, DOI: 10.1080/03050068.2019.1638103

Zhang, T. (2017). Why do Chinese postgraduates struggle with critical thinking? Some clues from the higher education curriculum in China. Journal of Further and Higher Education, 41(6), 857-871, DOI: 10.1080/0309877X.2016.1206857

Zhuk, S. I. (2014). Ukrainian Maidan as the last anti-Soviet revolution, or the methodological dangers of Soviet nostalgia (Notes of an American Ukrainian historian from inside the field of Russian Studies in the United States). $A b$ Imperio, 2014(3), 195-208, DOI: 10.1353/imp.2014.0062 